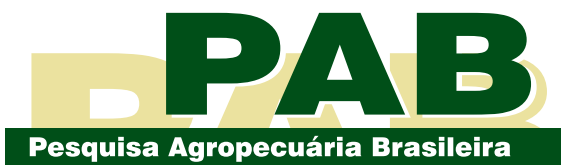

ISSN 1678-3921

Journal homepage: www.embrapa.br/pab

For manuscript submission and journal contents, access: www.scielo.br/pab

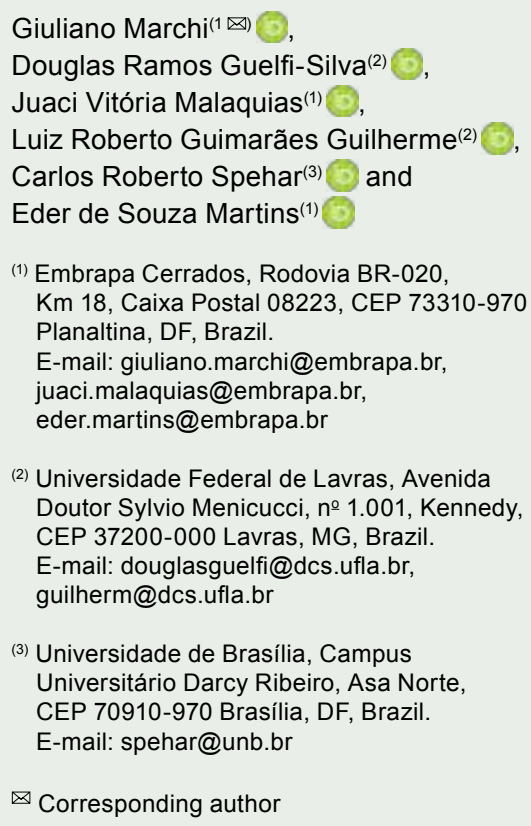

(2) Universidade Federal de Lavras, Avenida Doutor Sylvio Menicucci, № 1.001, Kennedy, CEP 37200-000 Lavras, MG, Brazil. E-mail: douglasguelfi@dcs.ufla.br, guilherm@dcs.ufla.br

(3) Universidade de Brasília, Campus Universitário Darcy Ribeiro, Asa Norte, CEP 70910-970 Brasília, DF, Brazil. E-mail: spehar@unb.br

$\bowtie$ Corresponding author

Received

May 24, 2018

Accepted

June 25, 2019

How to cite

MARCHI, G.; GUELFI-SILVA, D.R.;

MALAQUIAS, J.V.; GUILHERME, L.R.G.; SPEHAR, C.R.;MARTINS, E. de S. Solubility and availability of micronutrients extracted from silicate agrominerals. Pesquisa Agropecuária Brasileira, v.55, e00807, 2020. DOI: https://doi. org/10.1590/S1678-3921.pab2020.v55.00807.

\section{Solubility and availability of micronutrients extracted from silicate agrominerals}

\begin{abstract}
The objective of this work was to evaluate the solubility of the micronutrients copper, nickel, and zinc, chemically extracted from silicate agrominerals, as alternative sources of potassium for lettuce (Lactuca sativa) and rice (Oryza sativa) cultures, as well as their availability to the plants. The micronutrient contents of five agrominerals (alkaline ultramafic, biotite schist, volcanic breccia, phlogopite schist, and mining by-product from Chapada) were evaluated, after being extracted by the citric acid, hydrochloric acid, diethylenetriaminepentaacetic acid, 3051A, neutral ammonium citrate, and Mehlich-3 methods. The agrominerals, at the doses of 0 (control), 200, 400, and $600 \mathrm{~kg} \mathrm{ha}^{-1} \mathrm{~K}$, were mixed to soil where lettuce and rice were cultivated. The agrominerals presented a low solubility of $\mathrm{Ni}, \mathrm{Cu}$, and $\mathrm{Zn}$, with lower contents in lettuce shoots and rice grains than the corresponding soluble standards in sulfate form. The availability of micronutrients to the plants increased with the use of agrominerals, in comparison with the control. Similarities were observed in micronutrient solubility and availability between the different groups of agrominerals. The solubility and availability of $\mathrm{Cu}, \mathrm{Ni}$, and $\mathrm{Zn}$ depend on the solubility of the minerals that compose the agrominerals.
\end{abstract}

Index terms: copper, mining by-product, nickel, nutrient availability, zinc.

\section{Solubilidade e disponibilidade de micronutrientes extraídos de agrominerais silicáticos}

Resumo - O objetivo deste trabalho foi avaliar a solubilidade dos micronutrientes cobre, níquel e zinco, extraídos quimicamente de agrominerais silicáticos, como fonte alternativa de potássio para as culturas de alface (Lactuca sativa) e arroz (Oryza sativa), bem como sua disponibilidade para as plantas. Avaliaram-se os teores de micronutrientes de cinco agrominerais (ultramáfica alcalina, biotita xisto, brecha vulcânica, flogopita xisto e subproduto de mineração de Chapada), após extração pelos métodos ácido cítrico, ácido clorídrico, ácido dietilenotriamino penta-acético, 3051A, citrato neutro de amônio e Mehlich 3. Os agrominerais, nas doses de 0 (controle), 200,400 e $600 \mathrm{~kg} \mathrm{ha}^{-1}$ de $\mathrm{K}$, foram misturados em solo com cultivo de alface e arroz. Os agrominerais apresentaram baixa solubilidade de $\mathrm{Ni}, \mathrm{Cu}$ e $\mathrm{Zn}$, com menores teores em folhas de alface e grãos de arroz que o padrão solúvel correspondente na forma de sulfato. A disponibilidade de micronutrientes para as plantas aumentou com uso dos agrominerais, em comparação ao controle. Foram observadas similaridades na solubilidade e na disponibilidade de micronutrientes entre os diferentes grupos de agrominerais. A solubilidade $\mathrm{e}$ a disponibilidade de $\mathrm{Cu}$, $\mathrm{Ni}$ e $\mathrm{Zn}$ dependem da solubilidade dos minerais que compõem os agrominerais.

Termos para indexação: cobre, subproduto de mineração, níquel, disponibilidade de nutrientes, zinco. 


\section{Introduction}

The mineral ore productive chain in Brazil generates large amounts of waste, which, when discarded or not used properly, may cause environmental pollution. The use of these materials as agrominerals could reduce fertilizer costs and the damage to the environment, contributing to a sustainable production.

The possibility of using crushed rocks and/or mining waste as agrominerals has been evaluated for more than 65 years (Manning, 2010). Among these materials, silicates stand out to correct acidity and provide nutrients such as calcium, magnesium (Silva et al., 2012), and potassium (Guelfi-Silva et al., 2013; Silva et al., 2014). This is important since Brazil imports 95\% of K fertilizers (Castro \& Leite, 2018), leading to a search for alternative sources of this nutrient to reduce this dependency and enhance national security.

There is a great variety of agrominerals - such as "verdete de Abaeté" (Silva \& Lana, 2015), phonolite (Tavares et al., 2018), basalt and granite powder, alkaline ultramafic, alkaline breccia, biotite schist, and phlogopite schist (Ribeiro et al., 2010) -, with a diverse composition and mineralogy. These rocks also contain various chemical elements; some of them are essential to plants as mineral nutrients, whose availability varies according to the agromineral. However, the use of agrominerals in agriculture as soil amenders could be limited by the possible presence of heavy metals in high concentrations, especially since, when misused or discarded improperly, they could promote an increase of these elements in the soil (Guilherme et al., 2015).

Copper, nickel, and zinc are essential micronutrients for plant growth and development, and their presence in rock powders is beneficial (Marchi et al., 2008a), as long their concentrations do not reach toxic levels. However, the deficiency of those elements can also pose a serious problem in human nutrition. These nutrients may be found in great amounts in some crushed rocks and ore residues, which are liable to be used in agricultural areas as alternative fertilizers. Part of these nutrients is trapped in the solid matrix of rock particles, taking from decades to hundreds of years to solubilize in the soil, depending on climatic and edaphic conditions. Moreover, some rock materials, after applied to soils, may present residual effects even after many cropping cycles. Therefore, it is necessary to know the solubility and availability of these elements to plants.
The objective of this work was to evaluate the solubility of the micronutrients copper, nickel, and zinc, extracted chemically from silicate agrominerals, as alternative sources of potassium for lettuce and rice cultures, as well as their availability to the plants.

\section{Materials and Methods}

The experiment was performed at Universidade Federal de Lavras (UFLA), located in the municipality of Lavras, in the state of Minas Gerais, Brazil. Initially, 66 selected silicate agrominerals and mining rejects, potential sources of $\mathrm{K}$, collected in several parts of the country, were chemically characterized. The used methods were: $4 \mathrm{~A}$ and $4 \mathrm{~B}$, based on the lithium tetraborate/metaborate fusion of samples (Acme Analytical Laboratories, 2000); and 1DX method, where $0.50 \mathrm{~g}$ samples leached with $3 \mathrm{~mL}$ of 2:2:2 $\mathrm{HCl}: \mathrm{HNO}_{3}: \mathrm{H}_{2} \mathrm{O}$, at $95^{\circ} \mathrm{C}$, for 1 hour were diluted to $10 \mathrm{~mL}$ and then analyzed by inductively coupled plasma mass spectrometry (ISO, 1995; United States, 1996; Acme Analytical Laboratories, 2000). Based on the chemical results, for the current study, five agromineral samples - alkaline ultramafic, biotite schist, alkaline breccia, phlogopite schist, and mining by-product - were selected for higher $\mathrm{K}$ content; $\mathrm{Cu}$, $\mathrm{Ni}$, and $\mathrm{Zn}$ contents; and low content of heavy metals (Table 1). It should be noted that the concentrations of heavy metals are below the limits imposed by Instrução Normativa $n^{\circ} 5$ (Brasil, 2016) for crushed rocks used as fertilizers.

Samples of alkaline ultramafic were obtained in Lages, in the state of Santa Catarina; this plutonic rock is composed of iron-magnesium minerals (olivine, pyroxene, and phlogopite), plagioclase, nepheline, and carbonates. Samples of biotite schist, a metamorphic rock related to emerald mining, were obtained in Nova Era, in the state of Minas Gerais; this formation is related to the interaction of granitic and ultramafic rocks. Samples of alkaline breccia from the volcanic neck formed during the Cretaceous period were obtained in Santo Antônio da Barra, in the state of Goiás. Samples of phlogopite schist, a metamorphic rock residue, were obtained from Campo Formoso, in the state of Bahia, at an emerald mining site; this rock is also formed by interactions between ultramafic rocks and granite. A mining by-product from Chapada (BPC), a residue from a gold ore flotation process, 
was obtained from a mine at Chapada, in the state of Goiás, and consisted of biotite schist, formed by the interaction of metasedimentary and granite rocks. These materials have been thoroughly described (Silva et al., 2012, 2014; Guelfi-Silva, 2013).

Total $\mathrm{Cu}, \mathrm{Ni}$, and $\mathrm{Zn}$ from agrominerals were obtained by aqua regia using the $1 \mathrm{DX}$ method (Table 1). Contents of soluble $\mathrm{Cu}, \mathrm{Ni}$, and $\mathrm{Zn}$ were determined by extraction with: $20 \mathrm{~g} \mathrm{~L}^{-1}$ citric acid at a ratio of 1:100 (Manual..., 2013); neutral ammonium citrate (NAC), at 1:100 (Manual..., 2013); $0.005 \mathrm{~mol} \mathrm{~L}^{-1}$ diethylenetriaminepentaacetic acid (DTPA) at 1:100 (Alcarde \& Vale, 2003); 3051A, $0.5 \mathrm{~g}$ of material placed into a microwave, digested in $9.0 \mathrm{~mL}$ nitric acid and $3.0 \mathrm{~mL}$ hydrochloric acid (United States, 1994); $0.5 \mathrm{~mol} \mathrm{~L}^{-1}$ hydrochloric acid for 2 hours, at $25^{\circ} \mathrm{C}$ (Manual..., 2013); and Mehlich-3, $0.2 \mathrm{~mol} \mathrm{~L}^{-1}$ acetic acid, $0.25 \mathrm{~mol} \mathrm{~L}^{-1}$ ammonium nitrate, $0.015 \mathrm{~mol}$ $\mathrm{L}^{-1}$ ammonium fluoride, $0.013 \mathrm{~mol} \mathrm{~L}^{-1}$ nitric acid, $0.001 \mathrm{~mol} \mathrm{~L}^{-1}$ ethylenediaminetetraacetic (EDTA) $2 \mathrm{~g}$ in $20 \mathrm{~mL}$ for $5 \mathrm{~min}$ (Mehlich, 1984). For the 1DX method, agrominerals were crushed to pass a $0.3-\mathrm{mm}$ mesh, whereas, for the other chemical extractions, crushed agrominerals had the same particle size as that used for fertilization in the field (Silva et al., 2012).

The analyses (chemical extractions directly from crushed agrominerals) were performed in three replicates. The respective supernatants were analyzed for $\mathrm{Cu}, \mathrm{Ni}$, and $\mathrm{Zn}$ in the AAnalyst 800 atomic absorption spectrophotometer (PerkinElmer, Inc., Waltham, MA, USA). For the quality control of the 3051A EPA method, the standard reference material 2711 - Montana soil (Nist, 2003) from National Institute of Standards and Technology was used.

The content of $\mathrm{Cu}, \mathrm{Ni}$, and $\mathrm{Zn}$ in lettuce (Lactuca sativa L.) shoots and rice (Oryza sativa L.) grains was evaluated in an experiment carried out in a greenhouse in 2010; these species were selected as they may represent the main foods (leaves and grains) for humans. For this, soil samples of a Latossolo Vermelho distrófico (Santos et al., 2018), i.e., an Oxisol Ustox Acrustox (USDA, 2015), were collected in Itutinga, in the state of Minas Gerais, under native Cerrado vegetation, at the depth of $0-20 \mathrm{~cm}$. The soil was air dried, homogenized, and placed in 3-kg pots. The soil analysis (Teixeira et al., 2017) presented the following physicochemical characteristics: $5.4 \mathrm{pH}_{(\mathrm{H} 2 \mathrm{O})} ; 0.9$ and $22 \mathrm{mg} \mathrm{dm}^{-3} \mathrm{P}$ and $\mathrm{K}$, respectively, by Mehlich $1\left(0.05 \mathrm{~mol} \mathrm{~L}^{-1} \mathrm{HCl}+0.05 \mathrm{~mol} \mathrm{~L}^{-1} \mathrm{H}_{2} \mathrm{SO}_{4}\right.$; 1:5 soil:solution ratio); $5.4 \mathrm{mg} \mathrm{dm}^{-3} \mathrm{~S} ; 0.1 \mathrm{cmol}_{\mathrm{c}} \mathrm{dm}^{-3}$ $\mathrm{Ca}, \mathrm{Mg}$, and $\mathrm{Al}$ by $1.0 \mathrm{~mol} \mathrm{~L}^{-1} \mathrm{KCl} ; 1.7 \mathrm{cmol}_{\mathrm{c}} \mathrm{dm}^{-3}$ $\mathrm{H}+\mathrm{Al}\left(0.5 \mathrm{~mol} \mathrm{~L}^{-1} \mathrm{Ca}(\mathrm{OAc})_{2}\right.$, $\left.\mathrm{pH} 7.0\right)$; effective cation exchange capacity (CEC) of $0.4 \mathrm{cmol}_{\mathrm{c}} \mathrm{dm}^{-3}$; CEC at $\mathrm{pH} 7.0$ of $2.0 \mathrm{cmol}_{\mathrm{c}} \mathrm{dm}^{-3} ; 27.4,0.7,0.037$, and 0.5 of the micronutrients $\mathrm{Fe}, \mathrm{Cu}, \mathrm{Ni}$, and $\mathrm{Zn}$, respectively, extracted by DTPA (1:2 soil:solution ratio, for 2 hours); $0.4 \mathrm{mg} \mathrm{dm}^{-3} \mathrm{Mn}$ by Mehlich 1; $0.5 \mathrm{mg} \mathrm{dm}^{-3} \mathrm{~B}$ by hot water; $600 \mathrm{~g} \mathrm{~kg}^{-1}$ sand; $170 \mathrm{~g} \mathrm{~kg}^{-1}$ silt; and $230 \mathrm{~g} \mathrm{~kg}^{-1}$ clay.

The experimental design was completely randomized. Treatments were distributed in a $4 \times 6$ factorial arrangement, with five crushed agrominerals (ultramafic, biotite schist, breccia, phlogopite schist, and BPC) used as alternative fertilizer, together with soluble sources of $\mathrm{Ni}, \mathrm{Cu}$, and $\mathrm{Zn}$ in the form of sulfates; four doses of agrominerals were used, based on $0,200,400$, and $600 \mathrm{~kg} \mathrm{ha}^{-1} \mathrm{~K}$ (Table 2), with four replicates.

The micronutrients $\mathrm{Cu}, \mathrm{Ni}$, and $\mathrm{Zn}$ in soluble form were added to the $3-\mathrm{kg}$ pots as a control. The used doses - estimated from the values obtained by the direct extraction of crushed agrominerals by aqua regia

Table 1. Total content of nutrients and other elements from silicate agrominerals ${ }^{(1)}$.

\begin{tabular}{|c|c|c|c|c|c|c|c|c|c|c|c|c|c|c|c|c|c|c|}
\hline Agrol & $\mathrm{K}$ & $\mathrm{P}$ & $\mathrm{Ca}$ & $\mathrm{Mg}$ & $\mathrm{Si}$ & $\mathrm{Al}$ & $\mathrm{Fe}$ & $\mathrm{Ti}$ & $\mathrm{Mn}$ & $\mathrm{Cr}$ & $\mathrm{Na}$ & $\mathrm{Pb}$ & As & $\mathrm{Cd}$ & Mo & $\mathrm{Cu}$ & $\mathrm{Ni}$ & $\mathrm{Zn}$ \\
\hline & & & & & $----(n$ & $\left.g^{-1}\right)$ & & & & 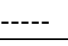 & & & & & 1) & & & --- \\
\hline Ultr & 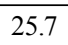 & 5. & 92.9 & 111.6 & 184.3 & 37.9 & 98.5 & 17.2 & 1.7 & 1.16 & 12.7 & 19.1 & 2.3 & 0.1 & 3.4 & 87 & 444 & 93 \\
\hline Biotite sc & & 0.3 & 37.7 & 83.8 & 246.5 & 55.3 & 71.0 & 2.7 & 1. & 1.51 & 6.4 & 10.3 & 0.6 & $<0.1$ & 5.8 & 54 & & 151 \\
\hline Breccia & 18.1 & 4.1 & 64.5 & 42.8 & 183.7 & 66.7 & 89.7 & 26.9 & 1.5 & 0.14 & 2.3 & 6.2 & $<0.5$ & $<0.1$ & 1.0 & 92 & 142 & 52 \\
\hline Phlogopite & 4.0 & 0.9 & 7.0 & 138.0 & 215.5 & 55.4 & 52.1 & 1.1 & 1.6 & 4.24 & 1.2 & 8.9 & $<0.5$ & 0.4 & 102.8 & 13 & 432 & 149 \\
\hline $\mathrm{BPC}^{(3)}$ & 28.1 & 0.8 & 22.8 & 23.4 & 268.0 & 82.5 & 56.1 & 2.0 & 0.4 & 0.03 & 12.0 & 34.8 & $<0.5$ & 0.7 & 9.9 & 448 & 20 & 124 \\
\hline
\end{tabular}

${ }^{(1)}$ Agrominerals crushed to pass a $0.3-\mathrm{mm}$ sieve. $\mathrm{K}, \mathrm{P}, \mathrm{Ca}, \mathrm{Mg}, \mathrm{Si}, \mathrm{Al}, \mathrm{Fe}, \mathrm{Ti}, \mathrm{Mn}, \mathrm{Cr}$, and Na were extracted by the 4A \& 4B method (Acme Analytical Laboratories, 2000). $\mathrm{Na}, \mathrm{Pb}, \mathrm{As}, \mathrm{Cd}, \mathrm{Mo}, \mathrm{Cu}, \mathrm{Ni}$, and $\mathrm{Zn}$ were extracted by the 1DX method (ISO, 1995; United States, 1996; Acme Analytical Laboratories, 2000). ${ }^{(3)}$ Mining by-product from Chapada, in the state of Goiás, Brazil. 
- were: $0,0.0027,1.027$, and $2.027 \mathrm{mg} \mathrm{kg}^{-1} \mathrm{CuSO}_{4} ; 0$, $0.005,0.216$, and $0.432 \mathrm{mg} \mathrm{kg}^{-1} \mathrm{NiSO}_{4}$; and $0,0.008$, 36.486 , and $72.973 \mathrm{mg} \mathrm{kg}^{-1} \mathrm{ZnSO}_{4}$.

Pots were incubated for a period of 100 days, with soil moisture kept constant at field capacity. After that, pots received ten seeds of lettuce or rice. Ten days after emergence, pots were thinned, leaving two vigorous, homogeneous plants in each one. The soil moisture of the pots was maintained constant at $70 \%$ (v/v), controlled by soil weight. Pots were rotated every week.

The experiment was harvested 120 days after emergence, when plants were cut near soil surface. From the harvested material, rice grains and lettuce shoots were collected and washed. All materials were placed in paper bags and dried at $75^{\circ} \mathrm{C}$ in a forced-air ventilation oven until constant weight for dry matter and yield evaluations. The dried material was milled and then $2.0 \mathrm{~g}$ were digested in concentrated $\mathrm{HNO}_{3}: \mathrm{HClO}_{4}$ $(3: 1)$, at $120^{\circ} \mathrm{C}$; the extracts were analyzed for $\mathrm{Ni}, \mathrm{Cu}$, and $\mathrm{Zn}$.

For the quality control of plant analyses, the certified reference material BCR 414-Plankton (European Commission, 2017) was used, based on known levels of $\mathrm{Cu}\left(29.5 \mathrm{mg} \mathrm{kg}^{-1}\right)$, Ni (18.8 $\left.\mathrm{mg} \mathrm{kg}^{-1}\right)$, and $\mathrm{Zn}$ (111.6 $\left.\mathrm{mg} \mathrm{kg}^{-1}\right)$. These micronutrient concentrations are the closest to the expected for lettuce, with recovery rates of 93,86 , and $92 \%$, respectively.

Regression lines were fitted to the data on $\mathrm{Cu}, \mathrm{Ni}$, and $\mathrm{Zn}$ plant content. The standard error of coefficients was tested for each parameter of quadratic equations fitted using data from crushed agrominerals and plant extractions; data normality was assessed by the Kolmogorov-Smirnov test, with Lilliefors correction, at $5 \%$ probability, and errors were evaluated by the constant variance (homoscedasticity) test, using a built-in feature of the Sigma Plot, version 12.0, software (Systat Software Inc., San Jose, CA, USA). Data from plant extractions were log transformed to correct skew and/or nonconstant variance, as appropriate.

The solubility of $\mathrm{Cu}, \mathrm{Ni}$, and $\mathrm{Zn}$ from crushed agrominerals, measured by chemical extractants, was correlated with the relative content (RC, \%) for each micronutrient in lettuce shoots and rice grains. The RC obtained for each crushed agromineral was weighted by the soluble source and calculated by the following equation: $\mathrm{RC}=100$ (Content $_{\text {rushed agromineral }}$ Content $_{\text {control }} /$ Content $_{\text {soluble sources }}$ - Content control $_{\text {, }}$, where Content $_{\text {crushed agromineral }}$ is the micronutrient in lettuce shoots or rice grains from the crushed agromineral; Content $_{\text {soluble source }}$ is the micronutrient in lettuce shoots or rice grains from the soluble source; and Content control $_{\text {. }}$ is the micronutrient in lettuce shoots or rice grains from the control (no fertilizer source).

Pearson's correlation analysis to relate the RC values and chemical extractants for each micronutrient was performed using the Sigma Plot, version 12.0, software (Systat Software Inc., San Jose, CA, USA). The complete set of agrominerals, considering each micronutrient, did not correlate with the RC. Therefore, Cook's distance influential point $\left(\mathrm{D}_{\mathrm{i}}\right)$ analysis, to find influential outliers in a set of predictor variables, was performed using the R software (R Core Team, 2017). Observations were kept separate from the group based on its influence on the analysis. Results were correlated using all $\mathrm{n}$ observations for the results, except the $i^{\text {th }}$ observation. The intent was to find, for each micronutrient, groups of agrominerals that could be analyzed by a determined extractant with the highest accuracy. The used guidelines were: if $D_{i}$

Table 2. Total amount (TA) of silicate agrominerals added to 3-kg pots and corresponding micronutrient content ${ }^{(1)}$.

\begin{tabular}{|c|c|c|c|c|c|c|c|c|c|c|c|c|c|c|c|}
\hline \multirow[t]{3}{*}{ Agromineral } & \multicolumn{5}{|c|}{$200 \mathrm{~kg} \mathrm{ha}^{-1} \mathrm{~K}$} & \multicolumn{5}{|c|}{$400 \mathrm{~kg} \mathrm{ha}^{-1} \mathrm{~K}$} & \multicolumn{5}{|c|}{$600 \mathrm{~kg} \mathrm{ha}^{-1} \mathrm{~K}$} \\
\hline & \multicolumn{2}{|c|}{ TA of agromineral } & \multirow{2}{*}{$\begin{array}{l}\mathrm{Cu} \\
---(\mathrm{mg}\end{array}$} & \multirow{2}{*}{$\begin{array}{l}\mathrm{Ni} \\
\mathrm{kg}^{-1} \mathrm{~S}\end{array}$} & \multirow{2}{*}{$\begin{array}{c}\mathrm{Zn} \\
\text { oil)--- }\end{array}$} & \multirow{2}{*}{\multicolumn{2}{|c|}{$\begin{array}{l}\text { TA of agromineral } \\
\left(\mathrm{g} \text { per pot) } \quad\left(\mathrm{g} \mathrm{kg}^{-1}\right)\right.\end{array}$}} & \multirow{2}{*}{$\begin{array}{l}\mathrm{Cu} \\
---(\mathrm{m} \\
\end{array}$} & \multirow{2}{*}{$\begin{array}{c}\mathrm{Ni} \\
\mathrm{kg}^{-1} \text { soi }\end{array}$} & \multirow{2}{*}{ Zn } & \multirow{2}{*}{\multicolumn{2}{|c|}{$\begin{array}{l}\text { TA of agromineral } \\
(\mathrm{g} \text { per pot })\left(\mathrm{g} \mathrm{kg}^{-1}\right)\end{array}$}} & \multirow{2}{*}{\multicolumn{3}{|c|}{$\begin{array}{l}\mathrm{Cu} \quad \mathrm{Ni} \quad \mathrm{Zn} \\
---\left(\mathrm{mg} \mathrm{kg}^{-1} \text { soil)--- }\right.\end{array}$}} \\
\hline & (g per pot) & $\left(\mathrm{g} \mathrm{kg}^{-1}\right)$ & & & & & & & & & & & & & \\
\hline Ultramafic & 11.66 & 3.9 & 0.34 & 1.73 & 0.36 & 23.33 & 7.78 & 0.68 & 3.45 & 0.72 & 35.0 & 11.7 & 1.01 & 5.18 & 1.08 \\
\hline Biotite schist & 17.47 & 5.8 & 0.31 & 1.33 & 0.88 & 34.93 & 11.64 & 0.63 & 2.65 & 1.76 & 52.4 & 17.5 & 0.94 & 3.98 & 2.64 \\
\hline Breccia & 16.58 & 5.5 & 0.51 & 0.24 & 0.29 & 33.17 & 11.06 & 1.02 & 0.47 & 0.57 & 49.7 & 16.6 & 1.53 & 0.71 & 0.86 \\
\hline Phlogopite & 4.69 & 1.6 & 0.02 & 0.68 & 0.23 & 9.38 & 3.13 & 0.04 & 1.35 & 0.47 & 14.1 & 4.7 & 0.06 & 2.03 & 0.7 \\
\hline $\mathrm{BPC}^{(2)}$ & 10.66 & 3.5 & 1.59 & 0.07 & 0.44 & 21.33 & 7.11 & 3.19 & 0.14 & 0.88 & 32.0 & 10.7 & 4.78 & 0.21 & 1.32 \\
\hline
\end{tabular}

(1)Based on the total content of copper, nickel, and zinc found in each crushed agromineral using aqua regia by the 1DX method (ISO, 1995; United States, 1996; Acme Analytical Laboratories, 2000). ${ }^{(2)}$ Mining by-product from Chapada, in the state of Goiás, Brazil. 
was greater than 0.5 , then the $\mathrm{i}^{\text {th }}$ data point was further investigated as it might be influential; and if $D_{i}$ was greater than 1 , then the $\mathrm{i}^{\text {th }}$ data point was quite likely to be influential.

\section{Results and Discussion}

The mass fractions of $\mathrm{Cu}, \mathrm{Ni}$, and $\mathrm{Zn}$ extracted from agrominerals by all chemical methods ranged from 0.1 to $54.1 \%,<0.1$ to $47.3 \%$, and $<0.1$ to $183.2 \%$, respectively (Table 3 ). Therefore, the solubility of these micronutrients from crushed agrominerals is variable, according to the adopted method. These results show that most of the $\mathrm{Cu}, \mathrm{Ni}$, and $\mathrm{Zn}$ in these materials is in matrix particles that have a very stable form and are not available for prompt plant uptake. Mixed with soils, great part of these micronutrients may be released in the long term (hundreds of years), depending on particle size and weathering intensity. This variability in the chemical analyzes of the crushed agrominerals may be an effect of granulometric variations among samples. In the present study, granulometry was not normalized to keep the samples the way they were going to be used in the field. The sieving and comminuting of agrominerals may increase their specific surface and the rate of nutrient release.

According to Silva et al. (2012), the values of $\mathrm{pH}$ in water from these materials were 9.4, 8.2, 8.3, 8.5, and 7.6 for ultramafic, biotite schist, breccia, phlogopite schist, and BPC, respectively. Depending on its composition, the agromineral may consume protons from the extractant solution, decreasing extractant ability to maintain the low $\mathrm{pH}$ values required for some methods, as well as $\mathrm{pH}$ stability when evaluating and comparing different materials, such as crushed agrominerals. A low material:solution ratio and highconcentration extractants are desirable when $\mathrm{pH}$ is the main mechanism in the process of extraction.

Among strong acids, $\mathrm{HCl}$ extracted high contents of $\mathrm{Cu}, \mathrm{Ni}$, and $\mathrm{Zn}$ from agrominerals (Table 3), whereas the 3051A method extracted lower amounts of $\mathrm{Cu}$ and $\mathrm{Ni}$. This was unexpected, as the samples are immersed in an acid medium in both methods. The 3051A method has an input of electromagnetic energy in a closed vessel, with increasing pressure and temperature above any open system (United States, 1994), but presents a higher material:solution ratio than $\mathrm{HCl}$. The difference among $\mathrm{Cu}, \mathrm{Ni}$, and $\mathrm{Zn}$ extracted

Table 3. Copper, nickel, and zinc contents $\left(\mathrm{mg} \mathrm{kg}^{-1}\right)$ extracted from crushed agrominerals by seven methods ${ }^{(1)}$.

\begin{tabular}{|c|c|c|c|c|c|c|c|}
\hline \multirow[t]{2}{*}{ Agromineral } & \multicolumn{7}{|c|}{ Method $^{(2)}$} \\
\hline & $3051 \mathrm{~A}$ & Citric acid & Hydrochloric acid & NAC & Mehlich 3 & DTPA & Aqua regia \\
\hline & \multicolumn{7}{|c|}{ Copper } \\
\hline Ultramafic & $13.8(0.7,15.9)$ & $4.3(1.4,4.9)$ & $47.2(1.9,54.1)$ & $6.7(2.1,7.7)$ & $1.1(0.1,1.3)$ & $0.8(0.0,1.0)$ & 87 \\
\hline Biotite schist & $4.3(0.3,7.9)$ & $1.9(0.4,3.6)$ & $5.7(1.2,10.5)$ & $9.6(4.7,17.8)$ & $0.6(0.1,1.1)$ & $0.07(0.0,0.1)$ & 54 \\
\hline Breccia & $10.7(1.9,11.6)$ & $3.9(0.7,4.2)$ & $31.1(0.8,33.8)$ & $9.0(1.3,9.8)$ & $0.5(0.1,0.6)$ & $0.1(0.0,0.1)$ & 92 \\
\hline Phlogopite & $2.0(1.2,15.1)$ & $3.7(2.0,28.0)$ & $6.0(1.0,45.3)$ & $7.2(2.2,54.0)$ & $0.8(0.2,5.9)$ & $0.1(0.0,0.7)$ & 13 \\
\hline \multirow[t]{2}{*}{$\mathrm{BPC}^{(3)}$} & $75.8(4.8,16.9)$ & $131.2(6.5,29.3)$ & $178.9(114.4,39.9)$ & $135.9(14.2,30.3)$ & $110.4(13.0,24.6)$ & $18.9(2.7,4.2)$ & 448 \\
\hline & \multicolumn{7}{|c|}{ Nickel } \\
\hline Ultramafic & $9.2(4.0,2.1)$ & $51.3(6.6,11.6)$ & $205.6(37.1,46.3)$ & $35.3(1.1,7.9)$ & $1.8(0.1,0.4)$ & $0.2(0.04,<0.1)$ & 444 \\
\hline Biotite schist & $1.2(0.04,0.5)$ & $4.5(1.5,2.0)$ & $36.2(6.2,15.9)$ & $4.8(4.5,2.1)$ & $0.6(0.2,0.2)$ & $0.04(0.01,<0.1)$ & 228 \\
\hline Breccia & $0.9(0.1,0.6)$ & $4.5(1.3,3.2)$ & $67.1(2.8,47.3)$ & $7.0(1.9,5.0)$ & $0.3(0.1,0.2)$ & $0.1(0.05,<0.1)$ & 142 \\
\hline Phlogopite & $5.7(1.3,1.3)$ & $12.8(1.2,3.0)$ & $108.8(37.2,25.2)$ & $14.4(2.5,3.3)$ & $4.5(0.2,1.0)$ & $0.3(<0.01,<0.1)$ & 432 \\
\hline \multirow[t]{2}{*}{$\mathrm{BPC}$} & $0.2(0.03,1.0)$ & $3.2(1.2,15.8)$ & $7.6(1.2,38.0)$ & $4.1(2.6,20.6)$ & $0.2(<0.01,0.6)$ & $0.01(0.01,<0.1)$ & 20 \\
\hline & \multicolumn{7}{|c|}{ Zinc } \\
\hline Ultramafic & $15.3(1.7,16.5)$ & $22.4(5.4,24.1)$ & $77.4(4.4,83.2)$ & $5.4(2.2,5.9)$ & $0.9(1.0,1.0)$ & $1.2(0.2,1.3)$ & 93 \\
\hline Biotite schist & $18.4(1.6,12.2)$ & $8.1(3.5,5.4)$ & $63.7(10.6,42,2)$ & $9.1(4.1,6.0)$ & $0.3(0.1,0.2)$ & $0.2(0.1,0.2)$ & 151 \\
\hline Breccia & $8.6(1.6,16.5)$ & $9.6(2.0,18.5)$ & $95.3(31.0,183.2)$ & $9.1(0.1,17.5)$ & $0.3(0.1,0.5)$ & $0.6(0.03,1.2)$ & 52 \\
\hline Phlogopite & $21.1(1.0,14.2)$ & $5.0(1.8,3.4)$ & $44.7(3.1,30.0)$ & $0.05(0.1,0.03)$ & $0.2(0.04,0.2)$ & $0.3(0.1,0.2)$ & 149 \\
\hline $\mathrm{BPC}$ & $16.6(1.8,13.4)$ & $20.8(7.8,16.7)$ & $63.1(1.2,50.9)$ & $6.6(4.0,5.3)$ & $0.4(0.1,0.4)$ & $0.6(0.1,0.5)$ & 124 \\
\hline
\end{tabular}

(1)Values between parentheses indicate standard deviation followed by the percentage of the total extracted by aqua regia. Results are arithmetic means from three replicates. ${ }^{(2)}$ Methods followed by references: 3051A (United States, 1994); citric acid (Manual..., 2013); hydrochloric acid (Manual..., 2013); NAC, neutral ammonium citrate (Manual..., 2013); Mehlich 3 (Mehlich, 1984); DTPA (Alcarde \& Vale, 2003); and aqua regia by the 1DX method (ISO, 1995; United States, 1996; Acme Analytical Laboratories, 2000). ${ }^{(3)}$ Mining by-product from Chapada, in the state of Goiás, Brazil. 
by $3051 \mathrm{~A}$ or $\mathrm{HCl}$, therefore, depending on the material being analyzed, may be related to proton consumption from the extractant by the hydroxyls released from agrominerals or even to contact time.

The 3051A method accesses potentially available mineral elements in the environment - specifically in sediments, sludge, soils, and oils (United States, 1994); the same principle may be applied to agrominerals. The difference between the total content extracted by aqua regia and by 3051A could be classified as nonavailable to plants, retained in the rock matrix and hardly dissolved in a short time. Ni extracted by 3051A from all agrominerals was lower than that extracted by aqua regia, citric acid, hydrochloric acid, and NAC (Table 3). Although concentrated acids seem to release more $\mathrm{Ni}$, the soil:solution ratio is still relevant for this kind of analysis, and pressure and temperature from the 3051A method may not work on crushed agrominerals with the same efficiency as on oils, sediments, sludge, and soils.

Pearson's correlations (r) among $\mathrm{Cu}$ chemical extractants (Table 3) and $\mathrm{RC}$ values were all above $0.97(\mathrm{p}<0.01)$. For $\mathrm{Ni}$, the groups of extractants with $\mathrm{r}$ above 0.90 were: citric acid, 3051A, $\mathrm{HCl}$, and NAC; Mehlich 3 and DTPA; and aqua regia and 3051A. For $\mathrm{Zn}$, there were two groups with $\mathrm{r}$ above $0.90-3051 \mathrm{~A}$ and aqua regia; and Mehlich 3 and DTPA -, and one group with $\mathrm{r}$ below $-0.90-\mathrm{HCl}$ and 3051A. For $\mathrm{Cu}$, the high correlation values among extractants may be related to the presence of this micronutrient in minerals whose dissolution rate is similar, while for $\mathrm{Ni}$ and $\mathrm{Zn}$ the extraction may be variable among chemical extractants if these micronutrients are enclosed in the minerals. Silva et al. (2012) showed that Mehlich-3 extracts from three Oxisols presented a low correlation with $\mathrm{Cu}$ and $\mathrm{Zn}$ contents in lettuce shoots, but a significant one with $\mathrm{Ni}$.

The applied doses of $\mathrm{Cu}, \mathrm{Ni}$, and $\mathrm{Zn}$ differed significantly in each treatment (Table 2 and Figure 1). The contents of these nutrients also varied in each agromineral, which was applied taking into account the amount of potassium it contained. Despite this, the added amounts of micronutrients, in all treatments, were relevant as the soil presented low $\mathrm{Cu}, \mathrm{Ni}$, and $\mathrm{Zn}$ contents of $0.7,0.037$, and $0.5 \mathrm{mg} \mathrm{dm}^{-3}$ soil, respectively, extracted by DTPA.

There was no correlation among the doses of $\mathrm{Cu}, \mathrm{Ni}$, and $\mathrm{Zn}$ from crushed agrominerals and the concentrations found in plant tissues (Figure 1). The absorption of micronutrients depends on the kind and solubility of the mineral that contains them and that composes each agromineral, as well as on soil $\mathrm{pH}$ after the agrominerals react with the soil. The applied agrominerals present different mineralogical compositions, resulting in a varying micronutrient availability for plants. Soil $\mathrm{pH}$ differed with each agromineral source and application rate, affecting $\mathrm{Cu}, \mathrm{Ni}$, and $\mathrm{Zn}$ availability. With the increase of agromineral doses applied to the soil, $\mathrm{pH}$ values also increased, depending on the agromineral, but remained within $\mathrm{pH}$ values of 5 to 6 (Silva et al., 2012).

Ultramafic and BPC, at the highest dose, increased soil $\mathrm{pH}$ to near 6.0 , while breccia increased the $\mathrm{pH}$ to 5.2 (Figure 1). Increases in $\mathrm{pH}$ raise negative charges on the surface of soil particles, causing the retention and, possibly, the hydroxide precipitation of $\mathrm{Cu}, \mathrm{Ni}$, and $\mathrm{Zn}$. Sulfide precipitation with increases in $\mathrm{pH}$ also effectively leads to the precipitation of these micronutrients. Although Peralta-Videa et al. (2002) found a greater accumulation of $\mathrm{Cu}, \mathrm{Ni}$, and $\mathrm{Zn}$ in alfalfa (Medicago sativa $\mathrm{L}$.) plants with increasing $\mathrm{pH}$ $(4.5,5.8$, and 7.1$)$, they concluded that heavy metals in the soil also affected plant micronutrient contents. According to these authors, at $\mathrm{pH}$ above $7.5, \mathrm{Cu}$ deficiencies must be monitored, whereas Brown et al. (1989) pointed out that, at $\mathrm{pH}<6.5$, most Ni compounds are relatively soluble. The $\mathrm{Cu}, \mathrm{Ni}$, and $\mathrm{Zn}$ contents in rice plants are ultimately correlated negatively with soil $\mathrm{pH}$ (Marchi et al., 2008b). Moreover, in all cases, $\mathrm{Cu}, \mathrm{Ni}$, and $\mathrm{Zn}$ availability is dependent on the concentration of competing ions and on the combination of chemical processes occurring in the soil (Caporale \& Violante, 2016).

At the highest doses of $\mathrm{CuSO}_{4}$ and $\mathrm{ZnSO}_{4}$, a total of 0.77 and $141.25 \mathrm{mg} \mathrm{kg}^{-1}$ rice grains, respectively (Figure 1), were obtained, representing 29 and $10 \%$ of the mean found for rice grains grown in the field in Indonesia (Herawati et al., 2000).

Phlogopite presented a higher $\mathrm{Cu}$ content in lettuce shoots and rice grains than the soluble source $\mathrm{CuSO}_{4}$ (Figure 1). In spite of the low dose of $\mathrm{Cu}$ added via phlogopite (Table 2), other factors such as nutrient balance, $\mathrm{pH}$, and soil conditioning may have contributed to increase $\mathrm{Cu}$ content in phlogopite treatments. Data from chemical extractants show that the $\mathrm{Cu}$ from phlogopite was extracted in a greater proportion than 

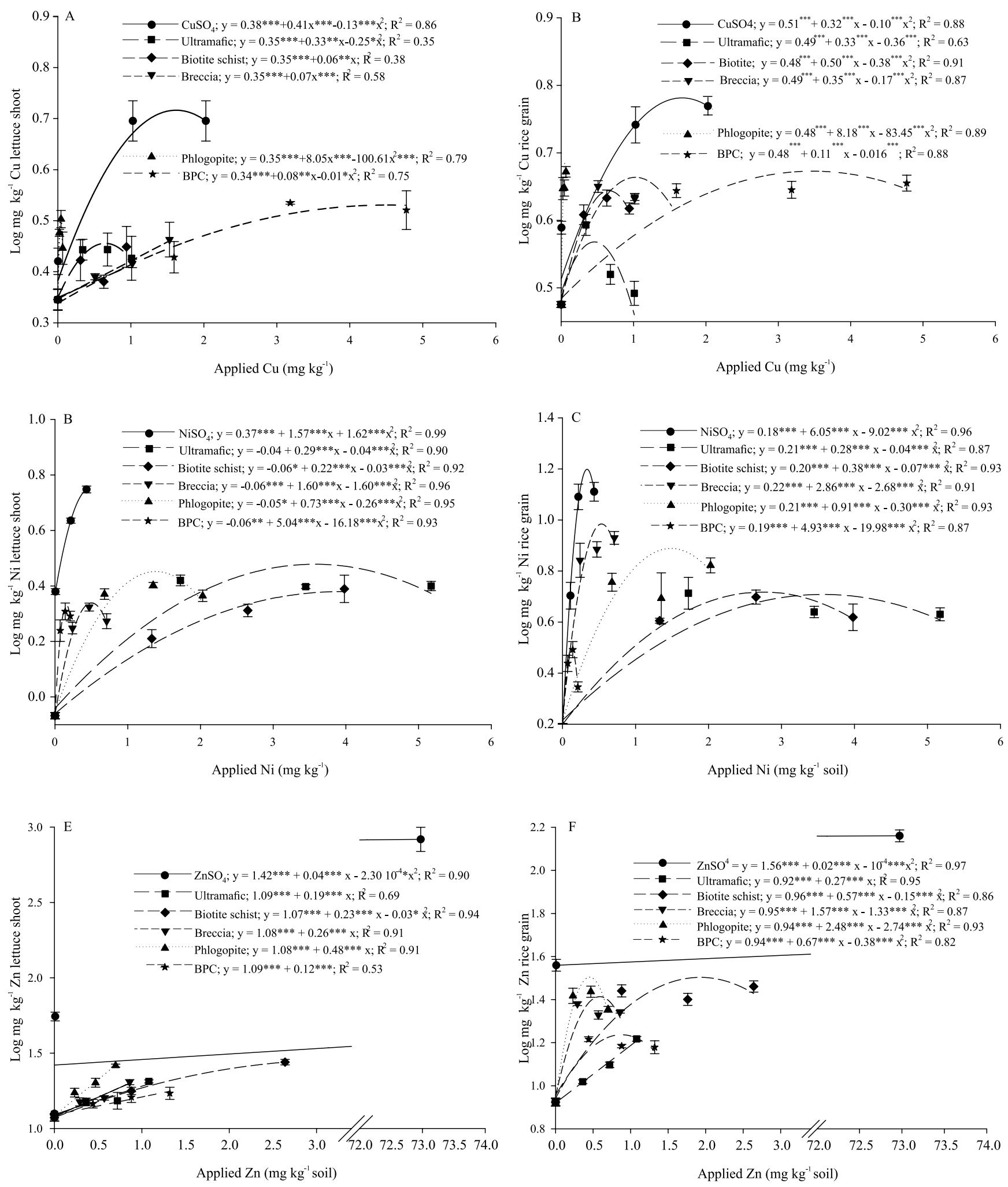

Figure 1. Copper, nickel, and zinc content in lettuce (Lactuca sativa) (A, C, and E, respectively) and rice (Oryza sativa) (B, $\mathrm{D}$, and F, respectively), grown in soils mixed with five agrominerals $(\mathrm{n}=4)$ and a soluble source. BPC, mining by-product from Chapada, in the state of Goiás, Brazil. $p<0.1 ; b^{* *}, p<0.05 ; b^{* * *}, p<0.01$. Error bars were calculated from standard errors. 
that from the other crushed agrominerals by citric acid, $\mathrm{NAC}, \mathrm{HCl}$, and Mehlich 3, when compared with the total amount by aqua regia (Table 3 ). The content of $\mathrm{Cu}$ from phlogopite and from the other agrominerals, except from the BPC, mainly by rice grains, where curves are steep, is indicative that $\mathrm{Cu}$ may be enclosed in an easily dissolved mineral, such as sulfide.

In the ultramafic treatment, $\mathrm{Cu}$ content was similar for lettuce and rice (Figure 1); however, when using the other crushed agrominerals, $\mathrm{Cu}$ content in the tissue was higher in rice, probably due to the translocation and concentration of the nutrient in the grains. It should be observed that, in rice, only the grains were analyzed, as it is the part used for human consumption.

$\mathrm{Ni}$ content in lettuce and rice showed a similar trend to that of $\mathrm{Cu}$, but with a lower concentration of $\mathrm{Ni}$ in lettuce. Although the ultramafic and biotite schist treatments were very rich in $\mathrm{Ni}$ (Table 2), this high dose was not translated into plant content. The low content of $\mathrm{Ni}$ in breccia promoted a higher Ni content in plants, mainly by rice grains, among treatments. However, the content of this micronutrient in plants from crushed agrominerals was much lower than that from the soluble source (Figure 1).

The content of $\mathrm{Zn}$ was similar in plants treated with agrominerals and with the soluble source (Figure 1). Plant content in from the smallest dose of soluble $\mathrm{Zn}$ was three times higher than that from the highest dose from crushed agrominerals. Therefore, agrominerals released a very low amount of the nutrient compared with its total content; however, soluble $\mathrm{Zn}$, even in small concentrations, is readily taken up by plants. In contrast, Fontes et al. (2014) found that increasing doses of $\mathrm{Zn}$ in the soil from 0 to $36 \mathrm{mg} \mathrm{dm}^{-3}$ caused a linear decrease in lettuce dry matter, but that $\mathrm{Zn}$ content increased from 0.1 to $1.25 \mathrm{mg} \mathrm{kg}^{-1}$ in the shoots; the highest dose used by these authors can be compared with the control of the present study.

The uptake of $\mathrm{Cu}, \mathrm{Ni}$, and $\mathrm{Zn}$ applied as soluble sources, even at extremely low doses, close to those available in agrominerals, outscored the content in plants exposed to agrominerals (Figure 1). Interestingly, the shape of the content curves of $\mathrm{Cu}, \mathrm{Ni}$, and $\mathrm{Zn}$ from crushed agrominerals changed abruptly, showing differences in the release rates among materials. As the contents of $\mathrm{ZnSO}_{4}$ were much higher than those added by agrominerals, the soluble curve is not well represented at low concentrations $\left(<3 \mathrm{mg} \mathrm{kg}^{-1}\right)$; however, the RC showed a good estimative of $\mathrm{Zn}$ uptake proportions among agromineral treatments and how far crushed agrominerals are from a high input of soluble $\mathrm{Zn}$ in the soil.

Contents of $\mathrm{Cu}$ in lettuce shoots and rice grains fertilized with agrominerals ranged from 2.2 to 4.0 and from 3.0 to $4.7 \mathrm{mg} \mathrm{kg}^{-1}$, respectively (Figure 1). Adequate contents of $\mathrm{Cu}$ in plant tissues should be from 1-5 and 20-30 $\mathrm{mg} \mathrm{kg}^{-1}$ according to Marschner (2012), since lower or higher values show a possible deficiency or toxicity by $\mathrm{Cu}$. Therefore, any increase in $\mathrm{Cu}$ availability in the studied Latossolo (Oxisol) would represent a gain, impacting positively crop yield, as the $\mathrm{Cu}$ concentration in the soil is considered to be average (Raij et al., 1996), which means that $\mathrm{Cu}$ should be applied to increase crop production. All studied agrominerals increased $\mathrm{Cu}$ content in the studied plants. The maximum uptake by plants was obtained with the highest applied dose of ultramafic and phlogopite, which increased $\mathrm{Cu}$ contents to $1.8 \mathrm{mg} \mathrm{kg}^{-1}$ in lettuce and to $1.7 \mathrm{mg} \mathrm{kg}^{-1}$ in rice grains, respectively.

Agromineral treatments increased $\mathrm{Ni}$ contents, which ranged from 1.03 to $2.11 \mathrm{mg} \mathrm{kg}^{-1}$ in lettuce shoots and from 2.06 to $8.61 \mathrm{mg} \mathrm{kg}^{-1}$ in rice grains (Figure 1). Breccia was the treatment that most increased $\mathrm{Ni}$ contents in the grains, even though the amount applied was smaller than that with ultramafic, biotite schist, and phlogopite (Table 2). The contents of $\mathrm{Ni}$ in the leaves of plants grown on uncontaminated soil ranges from 0.05 to $5.0 \mathrm{mg} \mathrm{kg}^{-1}$ dry weight (Brown, 2006). It should be pointed out that the plant $\mathrm{Ni}$ requirement of $<0.05 \mathrm{mg} \mathrm{kg}^{-1}$ dry weight is the lowest of any essential element, usually because there is no Ni soil deficiency. However, Ni can precipitate as hydroxide in soils with $\mathrm{pH}$ values above 6.7, and its deficiency may also be caused by the competition between ions such as $\mathrm{Zn}$, $\mathrm{Cu}$ and $\mathrm{MgO}$, as well as by other reactions in the soil (Brown et al., 1989). Regarding Ni fertilization, no criteria have been developed for lettuce, rice, and other crops. According to Hussain et al. (2013), contents higher than $10 \mathrm{mg} \mathrm{kg}^{-1} \mathrm{Ni}$ in plant tissues are considered toxic to sensitive plants and those above 50 $\mathrm{mg} \mathrm{kg}{ }^{-1} \mathrm{Ni}$ to tolerant plants. It should be highlighted that lettuce is Ni tolerant (Antonkiewicz et al., 2016).

The contents of $\mathrm{Zn}$ were low in the soil, but in the range of deficiency in lettuce shoots and rice grains in the control treatment, i.e., 11.5 and $8.4 \mathrm{mg} \mathrm{kg}^{-1}$, 
respectively. In all agromineral treatments, $\mathrm{Zn}$ contents in lettuce shoots and in rice grains varied from 14.1 to 27.6 and from 11.3 to $29 \mathrm{mg} \mathrm{kg}^{-1}$, respectively (Figure 1).

The $\mathrm{RC}$ of $\mathrm{Cu}$ in lettuce shoots at $0.5 \mathrm{mg} \mathrm{kg}^{-1} \mathrm{Cu}$ of soil, with ultramafic and biotite schist, was near to that of the soluble source, but, with breccia and the $\mathrm{BPC}$, it was low (Table 4). The $\mathrm{RC}$ values of $\mathrm{Cu}$ from phlogopite and of Ni from the BPC were not calculated because the soluble source curve was not adequate for all agrominerals, as aforementioned. The $\mathrm{RC}$ of $\mathrm{Cu}$ in rice grains with breccia was close to that of the soluble source. Varying the application dose from $0.5 \mathrm{mg} \mathrm{kg}^{-1}$ $\mathrm{Cu}$ caused changes in the $\mathrm{RC}$, as $\mathrm{Cu}$ uptake by plants did not present a linear relationship with the addition of agrominerals to the soil. In general, with the increase of the amount of applied agrominerals, the $\mathrm{Cu}, \mathrm{Ni}$, and $\mathrm{Zn}$ contents in plant tissues showed a downward trend, possibly due to increases in soil $\mathrm{pH}$.

The $\mathrm{RC}$, when correlated to $\mathrm{Cu}, \mathrm{Ni}$, and $\mathrm{Zn}$ contents extracted directly from agrominerals by chemical extractants, is indicative that the materials are of a very heterogeneous composition (Table 5). For this reason, the obtained correlation was low when using the whole set of materials; some of them - minerals of similar composition - present $\mathrm{Cu}, \mathrm{Ni}$, and $\mathrm{Zn}$, and can be grouped for analyses by determined extractants.

Table 4. Relative content of nickel, zinc, and copper in lettuce (Lactuca sativa) shoots and rice (Oryza sativa) grains from soil mixed with five agrominerals, using soluble sources as standards.

\begin{tabular}{|c|c|c|c|c|c|c|}
\hline \multirow[t]{3}{*}{ Agromineral } & \multicolumn{6}{|c|}{ Relative content $(\%)$} \\
\hline & \multicolumn{2}{|c|}{ At $0.5 \mathrm{mg} \mathrm{kg}^{-1} \mathrm{Cu}$} & \multicolumn{2}{|c|}{ At $0.4 \mathrm{mg} \mathrm{kg}^{-1} \mathrm{Ni}$} & \multicolumn{2}{|c|}{ At $0.5 \mathrm{mg} \mathrm{kg}^{-1} \mathrm{Zn}$} \\
\hline & Lettuce & Rice & Lettuce & Rice & Lettuce & Rice \\
\hline Ultramafic & 45.51 & 47.97 & 6.87 & 3.98 & 22.08 & 10.20 \\
\hline Biotite schist & 13.15 & 92.96 & 3.88 & 4.94 & 20.41 & 26.82 \\
\hline Breccia & 15.22 & 84.38 & 27.09 & 55.16 & 27.86 & 58.62 \\
\hline Phlogopite & - & - & 15.79 & 14.06 & 57.64 & 79.49 \\
\hline $\mathrm{BPC}^{(1)}$ & 12.13 & 28.59 & - & - & 14.53 & 23.37 \\
\hline
\end{tabular}

(1)Mining by-product from Chapada, in the state of Goiás, Brazil.

Table 5. Pearson's correlation analysis (within groups of agrominerals) of the copper, nickel, and zinc relative content values (\%) in lettuce (Lactuca sativa) shoots (LS) and rice (Oryza sativa) grains (RG) grown on crushed agrominerals, versus copper, nickel, and zinc extracted chemically from crushed agrominerals by seven methods $\left(\mathrm{mg} \mathrm{kg}^{-1}\right)^{(1)}$.

\begin{tabular}{|c|c|c|c|c|c|c|c|c|}
\hline \multirow[t]{2}{*}{ Agromineral group ${ }^{(2)}$} & \multirow[t]{2}{*}{ Plant } & \multicolumn{7}{|c|}{ Method $^{(3)}$} \\
\hline & & $3051 \mathrm{~A}$ & Citric acid & Hydrochloric acid & NAC & Mehlich-3 & DTPA & Aqua regia \\
\hline & & \multicolumn{7}{|c|}{ Copper (correlation coefficient; p-value) } \\
\hline Ultramafic, biotite schist (BS), and breccia & LS & $0.78 ; 0.42$ & $0.67 ; 0.53$ & $0.83 ; 0.38$ & $-0.99 ; 0.08$ & $0.981 ; 0.12$ & $1.00 ; 0.02$ & $0.44 ; 0.71$ \\
\hline Ultramafic, BS, and breccia & RG & $-0.85 ; 0.34$ & $-0.76 ; 0.45$ & $-0.89 ; 0.30$ & $1.00 ;<0.01$ & $-0.95 ; 0.20$ & $-0.99 ; 0.09$ & $-0.55 ; 0.63$ \\
\hline $\mathrm{BS}$, breccia, and $\mathrm{BPC}^{(4)}$ & LS & $-0.70 ; 0.51$ & $-0.75 ; 0.46$ & $-0.66 ; 0.54$ & $-0.76 ; 0.45$ & $-0.75 ; 0.45$ & $-0.75 ; 0.46$ & $-0.69 ; 0.51$ \\
\hline \multirow[t]{2}{*}{$\mathrm{BS}$, breccia, and BPC } & RG & $-0.99 ; 0.03$ & $-0.99 ; 0.07$ & $-1.00 ;<0.01$ & $-0.99 ; 0.08$ & $-0.99 ; 0.08$ & $-0.99 ; 0.08$ & $-0.99 ; 0.02$ \\
\hline & \multicolumn{8}{|c|}{ Nickel (correlation coefficient; p-value) } \\
\hline Ultramafic, BS, and flogopite & LS & $0.31 ; 0.80$ & $-0.11 ; 0.93$ & $0.16 ; 0.90$ & $0.03 ; 0.98$ & $0.99 ; 0.04$ & $0.89 ; 0.30$ & $0.66 ; 0.54$ \\
\hline Ultramafic, BS, and flogopite & RG & $-0.02 ; 0.99$ & $-0.43 ; 0.72$ & $-0.17 ; 0.89$ & $-0.29 ; 0.81$ & $0.92 ; 0.25$ & $0.70 ; 0.51$ & $0.38 ; 0.75$ \\
\hline Ultramafic, breccia, and flogopite & LS & $-1.00 ; 0.01$ & $-0.911 ; 0.27$ & $-0.96 ; 0.19$ & $-0.94 ; 0.21$ & $-0.41 ; 0.73$ & $-0.65 ; 0.55$ & $-0.91 ; 0.27$ \\
\hline \multirow[t]{2}{*}{ BS, breccia, and flogopite } & RG & $-0.40 ; 0.74$ & $-0.34 ; 0.77$ & $0.08 ; 0.95$ & $-0.12 ; 0.92$ & $-0.40 ; 0.74$ & $-0.19 ; 0.87$ & $-0.60 ; 0.59$ \\
\hline & \multicolumn{8}{|c|}{ Zinc (correlation coefficient; p-value) } \\
\hline Ultramafic, BS, breccia, flogopite, and BPC & LS & $0.41 ; 0.49$ & $-0.67 ; 0.21$ & $-0.51 ; 0.38$ & $-0.81 ; 0.09$ & $-0.43 ; 0.47$ & $-0.34 ; 0.58$ & $0.27 ; 0.66$ \\
\hline Ultramafic, BS, breccia, flogopite, and BPC & $\mathrm{RG}$ & $0.08 ; 0.90$ & $-0.80 ; 0.10$ & $-0.26 ; 0.67$ & $-0.50 ; 0.39$ & $-0.76 ; 0.14$ & $-0.55 ; 0.33$ & $0.04 ; 0.95$ \\
\hline Ultramafic, BS, flogopite and BPC & LS & $0.84 ; 0.16$ & $-0.70 ; 0.30$ & $-0.80 ; 0.19$ & $-0.90 ; 0.09$ & $-0.46 ; 0.54$ & $-0.34 ; 0.66$ & $0.44 ; 0.56$ \\
\hline Ultramafic, BS, flogopite and BPC & RG & $0.94 ; 0.05$ & $-0.79 ; 0.21$ & $-0.96 ; 0.04$ & $-0.81 ; 0.19$ & $-0.72 ; 0.27$ & $-0.60 ; 0.40$ & $0.67 ; 0.33$ \\
\hline
\end{tabular}

${ }^{(1)}$ Values in bold indicate correlation coefficients at a probability level lower than $10 \%$. (2) Group selection was aided by Cook's distance influential point analysis. ${ }^{(3)}$ Methods followed by references: 3051A (United States, 1994); citric acid (Manual..., 2013); hydrochloric acid (Manual..., 2013); NAC, neutral ammonium citrate (Manual..., 2013); Mehlich 3 (Mehlich, 1984); DTPA, diethylenetriaminepentaacetic acid (Alcarde \& Vale, 2003); and aqua regia by the 1DX method (ISO, 1995; United States, 1996; Acme Analytical Laboratories, 2000). ${ }^{(4)}$ Mining by-product from Chapada, in the state of Goiás, Brazil. 
The initial group of agrominerals considered for the correlations between the direct extractions from agrominerals and plant $\mathrm{Cu}$ uptake was: ultramafic, biotite schist, breccia, and BPC. $\mathrm{Cu}$ and $\mathrm{Zn}$ are in the form of sulfide in the BPC (Oliveira et al., 2016), but enclosed in silicates in the other agrominerals. After the $\mathrm{D}_{\mathrm{i}}$ analysis, the BPC was excluded from the group. The main groups and extractants are shown in Table 5. It should be noted that, for $\mathrm{Cu}$, high correlation values were obtained, but with a small sample of only three agrominerals.

The group of agrominerals considered for the correlations between direct extractions from agrominerals and $\mathrm{Ni}$ plant uptake was: ultramafic, biotite schist, breccia, and phlogopite. When breccia, which presents a high content of carbonates, was excluded from the group, the extractant that correlated with the RC of Ni for lettuce was Mehlich 3; however, when only biotite schist was excluded, the extractant was 3051A. Ni is enclosed in the biotite present in the biotite schist in the octahedral site (Gonnelli \& Renella, 2013), but it is enclosed in minerals such as olivine and serpentine in ultramafic and phlogopite. The absence of $\mathrm{Al}$ in the structure of these minerals facilitates Ni extraction by both chemical extractants and plants, when compared with biotite. No correlation was found when the $\mathrm{RC}$ of $\mathrm{Ni}$ for rice was analyzed even if the data of the agrominerals indicated in the $D_{i}$ analysis was excluded.

The complete set of agrominerals was used for the correlations between the direct extractions from agrominerals and plant Zn uptake. The NAC extractant correlated with $\mathrm{Zn}$ content in lettuce, while citric acid correlated with $\mathrm{Zn}$ content in rice grains. When breccia was excluded from the group, 3051A correlated with the $\mathrm{RC}$ of $\mathrm{Zn}$ for rice.

Agrominerals of different origins present a dissimilar chemical composition and are formed under diverse conditions, leading to varying granulometry when they are ground. Therefore, when they are applied to agricultural soils, the availability of micronutrients, such as $\mathrm{Cu}, \mathrm{Ni}$, and $\mathrm{Zn}$, to plants also varies. For these reasons, the chemical extractants used to evaluate the micronutrients directly from crushed agrominerals also showed variable results, which were not related to the total content of micronutrients in the agromineral. Selected groups of agrominerals - with similar minerals containing the micronutrients
- reacted similarly to some chemical extractants and allowed correlations with plant uptake. Therefore, the use of appropriate extractants for groups of silicate agrominerals may enable the prediction of the release and uptake of the evaluated micronutrients.

\section{Conclusions}

1. The agrominerals alkaline ultramafic, biotite schist, volcanic breccia, phlogopite schist, and Chapada mining by-product, after applied to the soil, increase copper, nickel, and zinc contents in lettuce (Lactuca sativa) shoots and rice (Oryza sativa) grains.

2. For each group of silicate agrominerals, there is a specific correlation between the solubility of $\mathrm{Cu}, \mathrm{Ni}$, and $\mathrm{Zn}$ and their availability to plants.

3. The solubility and availability of $\mathrm{Cu}, \mathrm{Ni}$, and $\mathrm{Zn}$ depend on the mineralogical composition of the silicate agrominerals.

\section{Acknowledgments}

To Conselho Nacional de Desenvolvimento Científico e Tecnológico (CNPq), for grant (number 575032/2008-1); and to Dr. José Carlos Sousa-Silva from Embrapa Cerrados, for his suggestions and contributions.

\section{References}

ACME Analytical Laboratories. Assessment report n²,6531. Vancouver: Geological Survey Branch, 2000. 277p. Available at: $<$ http://aris.empr.gov.bc.ca/ArisReports/26531B.PDF $>$. Accessed on: May 92019.

ALCARDE, J.C.; VALE, F. Solubilidade de micronutrientes contidos em formulações de fertilizantes, em extratores químicos. Revista Brasileira de Ciência do Solo, v.27, p.363-372, 2003. DOI: https://doi.org/10.1590/S0100-06832003000200016.

ANTONKIEWICZ, J.; JASIEWICZ, C.; KONCEWICZ-BARAN, M.; SENDOR, R. Nickel bioaccumulation by the chosen plant species. Acta Physiologiae Plantarum, v.38, art.40, 2016. DOI: https://doi.org/10.1007/s11738-016-2062-5.

BRASIL. Ministério da Agricultura, Pecuária e Abastecimento. Instrução Normativa n ${ }^{0}$ 5, de 10 de março de 2016. [Estabelece as regras sobre definições, classificação, especificações e garantias, tolerâncias, registro, embalagem, rotulagem e propaganda dos remineralizadores e substratos para plantas, destinados à agricultura]. 2016. Available at: <http://www.agricultura. gov.br/assuntos/insumos-agropecuarios/insumos-agricolas/ fertilizantes/legislacao/in-5-de-10-3-16-remineralizadores-esubstratos-para-plantas.pdf >. Accessed on: Aug. 272019. 
BROWN, P.H. Nickel. In: BARKER, A.V.; PILBEAM, D.J. (Ed.). Handbook of plant nutrition. Boca Raton: Taylor \& Francis, 2006. p.395-411.

BROWN, P.H.; DUNEMANN, L.; SCHULZ, R.; MARSCHNER, $\mathrm{H}$. Influence of redox potential and plant species on the uptake of nickel and cadmium from soils. Journal of Plant Nutrition and Soil Science, v.152, p.85-91, 1989. DOI: https://doi.org/10.1002/ jpln.19891520116.

CAPORALE, A.G.; VIOLANTE, A. Chemical processes affecting the mobility of heavy metals and metalloids in soil environments. Current Pollution Reports, v.2, p.15-27, 2016. DOI: https://doi. org/10.1007/s40726-015-0024-y.

CASTRO, C.; LEITE, R.M.V.B.C. Main aspects of sunflower production in Brazil. OCL, v.25, art.D104, 2018. DOI: https://doi.org/10.1051/ocl/2017056.

EUROPEAN COMMISSION. Joint Research Centre. Certified Reference Material BCR 414: Certificate of Analysis: Plankton. Geel, 2017. BCR 414.

FONTES, R.L.F.; PEREIRA, J.M.N.; NEVES, J.C.L. Uptake and translocation of $\mathrm{Cd}$ and $\mathrm{Zn}$ in two lettuce cultivars. Anais da Academia Brasileira de Ciências, v.86, p.907-922, 2014.

GONNELLI, C.; RENELlA, G. Chromium and nickel. In: ALLOWAY, B.J. (Ed.). Heavy metals in soils: trace metals and metalloids in soils and their bioavailability. $3^{\text {rd }}$ ed. Springer: Dordrecht, 2013. p.313-333. (Environmental Pollution, 22). DOI: https://doi.org/10.1007/978-94-007-4470-7_11.

GUELFI-SILVA, D.R.; MARCHI, G.; SPEHAR, C.R.; GUILHERME, L.R.G.; FAQUIN, V. Agronomic efficiency of potassium fertilization in lettuce fertilized with alternative nutrient sources. Revista Ciência Agronômica, v.44, p.267-277, 2013. DOI: https://doi.org/10.1590/s1806-66902013000200008.

GUILHERME, L.R.G.; MARCHI, G.; GONÇALVES, V.C.; PINHO, P.J. de; PIERANGELI, M.A.P.; REIN, T.A. Metais em fertilizantes inorgânicos: avaliação de risco à saúde após a aplicação. 2.ed. rev. e atual. Lavras: UFLA, 2015. 210p.

HERAWATI, N.; SUZUKI, S.; HAYASHI, K.; RIVAI, I.F.; KOYAMA, H. Cadmium, copper, and zinc levels in rice and soil of japan, indonesia, and china by soil type. Bulletin of Environmental Contamination and Toxicology, v.64, p.33-39, 2000.

HUSSAIN, M.B.; ALI, S.; AZAM, A.; HINA, S.; FAROOQ, M.A.; ALI, B.; BHARWANA, S.A.; GILL, M.B. Morphological, physiological and biochemical responses of plants to nickel stress: a review. African Journal of Agricultural Research, v.8, p.15961602, 2013. DOI: https://doi.org/10.5897/ajar12.407.

ISO. International Organization for Standardization. ISO 11466: Soil quality - extraction of trace elements soluble in aqua regia. Geneva, 1995.

MANNING, D.A.C. Mineral sources of potassium for plant nutrition. A review. Agronomy for Sustainable Development, v.30, p.281-294, 2010. DOI: https://doi.org/10.1051/agro/2009023.

MANUAL de métodos analíticos oficiais para fertilizantes e corretivos. Brasília: Ministério da Agricultura Pecuária e Abastecimento, Secretaria de Defesa Agropecuária, 2013. 150p.
MARCHI, E.C.S.; ALVARENGA, M.A.R.; MARCHI, G.; SILVA, C.A.; SOUZA FILHO, J.L. de. Efeito da adubação orgânica sobre as frações de carbono de solos cultivados com alface americana. Ciência e Agrotecnologia, v.32, p.1760-1766, 2008a. DOI: https://doi.org/10.1590/S1413-70542008000600013.

MARCHI, G.; MARCHI, E.C.S.; WANG, G.; MCGIFFEN, M. Effect of age of a sorghum-sudangrass hybrid on its allelopathic action. Planta Daninha, v.26, p.707-716, 2008b. DOI: https://doi.org/10.1590/S0100-83582008000400001.

MARSCHNER, P. Marschner's mineral nutrition of higher plants. $3^{\text {rd }}$ ed. Amsterdam: Elsevier, 2012. 651p.

MEHLICH, A. Mehlich 3 soil test extractant: a modification of Mehlich 2 extractant. Communications in Soil Science and Plant Analysis, v.15, p.1409-1416, 1984. DOI: https://doi.org/10.1080/00103628409367568.

NIST. National Institute of Standards \& Technology. Certificate of Analysis: Standard Reference Material 2711. Gaithersburg, 2003. SRM 2711.

OLIVEIRA, C.G. de; OLIVEIRA, F.B. de; DELLA GIUSTINA, M.E.S.; MARQUES, G.C.; DANTAS, E.L.; PIMENTEL, M.M.; BUHN, B.M. The Chapada $\mathrm{Cu}-\mathrm{Au}$ deposit, Mara Rosa magmatic arc, Central Brazil: constraints on the metallogenesis of a Neoproterozoic large porphyry-type deposit. Ore Geology Reviews, v.72, p.1-21, 2016. DOI: https://doi.org/10.1016/j. oregeorev.2015.06.021.

PERALTA-VIDEA， J.R.; GARDEA-TORRESDEY， J.L.; GOMEZ, E.; TIEMANN, K.J.; PARSONS, J.G.; CARRILLO, G. Effect of mixed cadmium, copper, nickel and zinc at different pHs upon alfalfa growth and heavy metal uptake. Environmental Pollution, v.119, p.291-301, 2002. DOI: https://doi.org/10.1016/ S0269-7491(02)00105-7.

R CORE TEAM. R: a language and environment for statistical computing. Version 3.3.3. Vienna: R Foundation for Statistical Computing, 2017.

RAIJ, B.V.; CANTARELLA, H.; QUAGGIO, J.A.; FURLANI, A.M.C. Recomendações de adubação e calagem para o estado de São Paulo. $2^{\text {nd }}$ ed. Campinas, São Paulo, Instituto Agronômico, 1996. 285p.

RIBEIRO, L. da S.; SANTOS, A.R. dos.; SOUZA, L.F. da S.; SOUZA, J.S. Rochas silicáticas portadoras de potássio como fontes do nutriente para as plantas solo. Revista Brasileira de Ciência do Solo, v.34, p.891-897, 2010. DOI: https://doi.org/10.1590/s0100-06832010000300030.

SANTOS, H.G. dos; JACOMINE, P.K.T.; ANJOS, L.H.C. dos; OLIVEIRA, V.A. de; LUMBRERAS, J.F.; COELHO, M.R.; ALMEIDA, J.A. de; ARAUJO FILHO, J.C. de; OLIVEIRA, J.B. de; CUNHA, T.J.F. Sistema brasileiro de classificação de solos. 5.ed. rev. e ampl. Brasília: Embrapa, 2018. E-book.

SILVA, A.A.; LANA, R.M.Q. Incubação do verdete com diferentes fontes de ácidos para disponibilização de potássio, cálcio, magnésio do solo. Holos, v.5, p.73-83, 2015. DOI: https://doi.org/10.15628/holos.2015.3210.

SILVA, D.R.G.; MARCHI, G.; SPEHAR, C.R.; GUILHERME, L.R.G.; REIN, T.A.; SOARES, D.A.; ÁVILA, F.W. 
Characterization and nutrient release from silicate rocks and influence on chemical changes in soil. Revista Brasileira de Ciência do Solo, v.36, p.951-962, 2012. DOI: https://doi.org/10.1590/s0100-06832012000300025.

SILVA, D.R.G.; SPEHAR, C.R.; MARCHI, G.; SOARES, D. de A.; CANCELLIER, E.L.; MARTINS, E. de S. Yield, nutrient uptake and potassium use efficiency in rice fertilized with crushed rocks. African Journal of Agricultural Research, v.9, p.455-464, 2014. DOI: https://doi.org/10.5897/ajar2013.7638.

TAVARES, L. de F.; CARVALHO, A.M.X. de; CAMARGO, L.G.B.; PEREIRA, S.G. de F.; CARDOSO, I.M. Nutrients release from powder phonolite mediated by bioweathering actions. International Journal of Recycling of Organic Waste in Agriculture, v.7, p.89-98, 2018. DOI: https://doi.org/10.1007/ s40093-018-0194-x.
TEIXEIRA, P.C.; DONAGEMMA, G.K.; FONTANA, A.; TEIXEIRA, W.G. (Ed.). Manual de métodos de análise de solo. 3.ed. rev. e ampl. Brasília: Embrapa, 2017. 574p.

UNITED STATES. Environmental Protection Agency. Method 3050b: acid digestion of sediments, sludges and soils. Washington, 1996.

UNITED STATES. Environmental Protection Agency. Method 3051A: microwave assisted acid digestion of sediments, sludges, soils, and oils. Washington, 1994.

USDA. United States Department of Agriculture. Illustrated guide to soil taxonomy. Version 2.0. Lincoln: U.S. Department of Agriculture, Natural Resources Conservation Services, National Soil Survey Center, 2015. 